\title{
MENYUSUN LAPORAN KEUANGAN
}

Makalah ini disusun untuk memenuhi tugas mata kuliah kewirausahaan

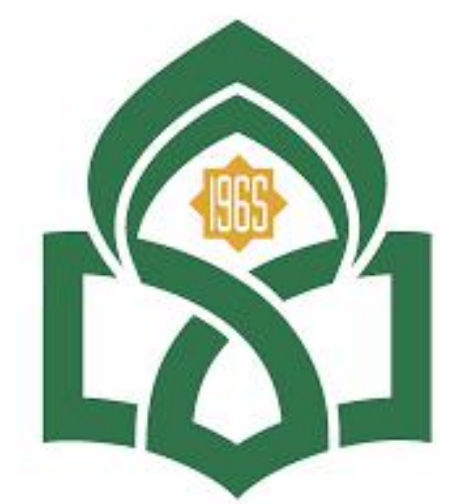

UNIVERSITAS ISLAM NEGERI

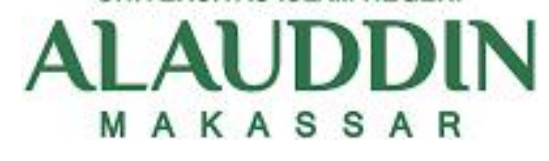

DI SUSUN OLEH :

DAHLIA

90500120006

PERBANKAN SYARIAH

FAKULTAS EKONOMI DAN BISNIS ISLAM

UNIVERSITAS ISLAM NEGERI ALAUDDIN MAKASSAR 


\section{KATA PENGANTAR}

Assalamualaikum wr.wb

Puji syukur saya panjatkan atas kehadirat Allah SWT yang telah melimpahkan rahmat dan hidayahnya, sehingga saya dapat menyelesaikan tugas makalah ini yang berjudul "menyusun laporan keuangan". Tujuan dari makalah ini adalah untuk memenuhi tugas mata kuliah kewirausahaan. Saya mengucapkan terimah kasih kepada ibu Dra. $\mathrm{Hj}$. Nuraeni Gani, MM. selaku dosen yang telah memberikan tugas ini sehingga dapat menambah pengetahuan dan wawasan bagi setiap pembaca dan dapat diaplikasikan dalam kehidupan sehari-hari.

Takalar, 17 Desember 2021 


\section{DAFTAR ISI}

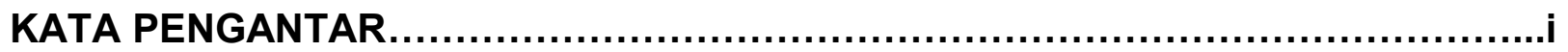

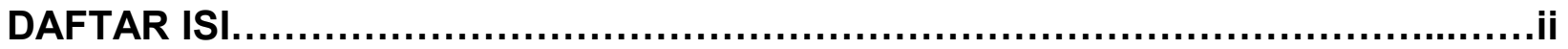

\section{BAB 1}

\section{PENDAHULUAN}

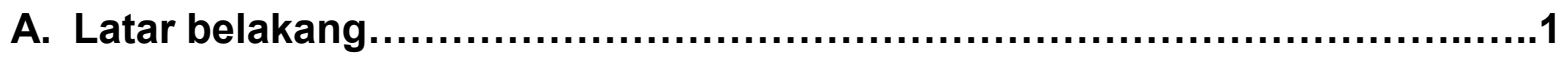

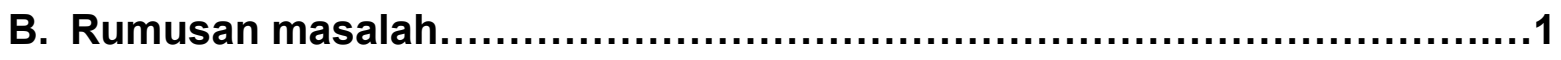

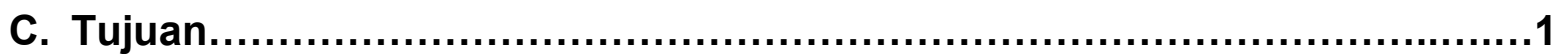

\section{BAB 2}

\section{PEMBAHASAN}

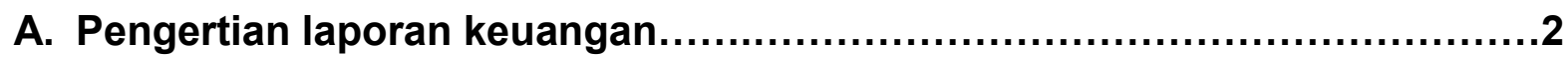

B. Tujuan laporan keuangan..............................................................

C. Jenis-jenis laporan keuangan.........................................................

D. Bentuk-bentuk laporan keuangan................................................4

\section{BAB 3}

PENUTUP

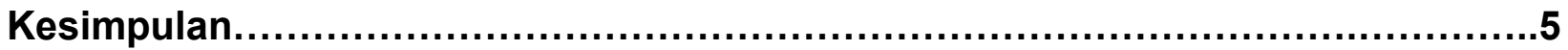

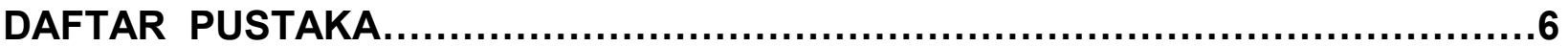




\section{BAB 1}

\section{PENDAHULUAN}

\section{A. Latar belakang}

laporan keuangan merupakan dasar dalam menentukan atau menilai posisi keuangan perusahaanmengemukakan bahwa laporan keuangan tersebut bertujuan sebagai laporan yang ditujukan kepada berbagai pengguna laporan keuangan yang memiliki kebutuhan informasi tentang keuangan secara umum yang tidak memiliki hak untuk meminta laporan keuangan tersebut dan disesuaikan untuk memenuhi kebutuhan informasi tertentu. Nantinya informasi tersebut digunakan sebagai acuan dalam pertimbangan dan pengambilan keputusan baik untuk pihak internal perusahaan maupun pihak eksternal perusahaan. Jika tujuan dasar laporan keuangan adalah sebagai informasi keuangan perusahaan, maka hendaknya penyajian laporan keuangan disusun sesuai dengan standar yang nantinya akan mempermudah manajemen perusahaan dalam pengambilan keputusan.

\section{B. Rumusan Masalah}

A. Apa pengertian laporan keuangan?

B. Apa saja tujuan dari laporan keuangan?

C. Sebutkan jenis-jenis laporan keuangan?

D. Sebutkan bentuk-bentuk laporan keuangan?

C. Tujuan Penulisan

a. Mengetahui pengertian laporan keuangan

b. Mengetahui tujuan dari laporan keuangan

c. Mengetahui jenis-jenis laporan keuangan

d. Mengetahui bentuk-bentuk laporan keuangan

\section{BAB 2}




\section{PEMBAHASAN}

\section{A. Pengertian Laporan Keuangan}

Laporan keuangan adalah laporan yang memuat informasi keuangan berupa jumlah kekayaan, jenis-jenis kekayaan seperti kewajiban-kewajiban (utang), baik dalam jangka pendek maupun jangka panjang, serta ekuitas (modal) dan hasil-hasil usaha yang dimiliki atau diperoleh suatu lembaga.

\section{B. Tujuan laporan keuangan}

- Memberikan informasi keuangan tentang jumlah aktiva (harta) dan jenis-jenis aktiva

- Memberikan informasi tentang jumlah kewajiban, jenis-jenis kewajiban, dan jumlah modal

- Memberikan informasi tentang hasil usaha yang tercermin dari jumlah pendapatan yang diperoleh dan sumber-sumber pendapatan

- Memberikan informasi tentang jumlah biaya yang dikeluarkan dalam jenis-jenis biaya pada periode tertentu

- Memberikan informasi tentang perubahan-perubahan yang terjadi dalam aktiva, kewajiban, dan modal suatu perusahaan

- Memberikan informasi tentang kinerja manajemen dalam suatu periode dari hasil laporan keuangan yang disajikan.

Pihak-pihak yang berkepentingan

- Pemegang saham

- Manajemen

- Kreditor

- Pemerintah

- Karyawan

- Investor

\section{Jenis-jenis laporan keuangan}


- Neraca yaitu laporan yang menunjukkan posisi keuangan perusahaan pada tanggal tertentu. Posisi keuangan yang dimaksud adalah posisi aktiva (harta), pasiva (kewajiban), dan ekuitas (modal) suatu perusahaan.

- Laporan laba rugi yaitu laporan keuangan yang menggambarkan hasil usaha dalam suatu periode tertentu. Laporan ini berisi komponen pendapatan yang diperoleh dan biaya yang telah dikeluarkan selama satu periode tertentu.

- Laporan arus kas yaitu laporan yang menunjukkan semua aspek yang berkaitan dengan kegiatan perusahaan, baik yang berpengaruhi langsung maupun tidak langsung terhadap kas.

- Laporan perubahan modal yaitu laporan yang berisi catatan terjadinya perubahan modal di perusahaan.

KOMPONEN LAPORAN KEUANGAN (NERACA)

- Aktiva lancer

- Penyertaan

- Aktiva tetap

- Aktiva lainnya

- Utang lancar (utang jangka pendek)

- Utang jangka panjang

- Ekuitas

KOMPONEN LAPORAN KEUANGAN (LAPORAN LABA RUGI)

- Penjualan (pendapatan)

- Harga Pokok Penjualan (HPP)

- Laba kotor

- Biaya operasi (biaya umum, biaya penjualan, biaya sewa, biaya administrasi)

- Laba kotor operasional

- Penyusutan (depresiasi) 
- Pendapatan bersih operasi

- Pendapatan lainnya

- Laba sebelum bunga dan pajak

- Biaya bunga (bunga wesel, bunga bank, bunga hipotek, bunga obligasi, bunga lainnya)

- Laba sebelum pajak

- Pajak

- Laba sesudah bunga dan pajak

- Laba per lembar saham

\section{Bentuk-bentuk laporan keuangan}

Ada dua bentuk-bentuk dalam laporan keuangan yaitu:

- Bentuk neraca terdiri dari bentuk skontro (account form) dan bentuk laporan atau vertikal (report form).

- Bentuk laporan laba rugi terdiri dari bentuk tunggal (single step system) dan bentuk majemuk (multiple step system). 


\section{PENUTUP}

\section{KESIMPULAN}

Laporan keuangan adalah catatan informasi keuangan suatu perusahaan pada suatu periode akuntansi yang dapat digunakan untuk menggambarkan kinerja perusahaan tersebut. .Catatan dan laporan lain serta materi penjelasan yang merupakan bagian tak terpisahkan dari laporan keuangan. Penyusunan laporan keuangan memiliki peranan yang sangat penting dalam suatu perusahaan. Sebab laporan keuangan merupakan dasar dalam menentukan atau menilai posisi keuangan perusahaanmengemukakan bahwa laporan keuangan tersebut bertujuan sebagai laporan yang ditujukan kepada berbagai pengguna laporan keuangan yang memiliki kebutuhan informasi tentang keuangan secara umum yang tidak memiliki hak untuk meminta laporan keuangan tersebut dan disesuaikan untuk memenuhi kebutuhan informasi tertentu.

Setiap perusahaan, baik perusahaan besar, menengah maupun kecil wajib membuat laporan keuangan ini pada setiap periode. Tujuan laporan keuangan adalah untuk memberikan informasi yang berguna bagi investor dan kreditor dalam pengambilan keputusan investasi dan kredit. 
Muawanah, U dan F. Poernawati. 2008. Konsep Dasar Akuntansi Dan Pelaporan

Keuangan. Edisi Ketiga. Direktorat Pembinaan Sekolah Menengah Kejuruan. Jakarta. 